\title{
Distribution and Expression of Visfatin-Positive Cells in the Spleen of Lipopolysaccharide-Stimulated Piglets
}

\author{
Distribución y Expresión de Células Visfatin Positivas en \\ el Bazo de Lechones Estimulados con Lipopolisacáridos
}

Ke Xiao*; Chang-Wei Qiu*; Min Chen**; Zhi Yang*; Jing Wang*; Ke-Mei Peng* \& Hui Song*

XIAO, K.; QIU, C-W.; CHEN, M.; YANG, Z.; WANG, J.; PENG, K-M. \& SONG, H. Distribution and expression of visfatin-positive cells in the spleen of lipopolysaccharide-stimulated piglets. Int. J. Morphol., 32(4):1457-1463, 2014.

SUMMARY: The histological changes in the spleen and the immunohistochemical expression of visfatin in lipopolysaccharidestimulated piglets are reported to examine the relation between visfatin and inflammation. The results are as follows: (1) After LPS treated, the spleen displayed thicker capsules and trabecula, the thinner periarterial lymphatic sheath, and the more expandable splenic sinusoid, with an increase in the number of splenic nodules, lymphocytes, ellipsoids of the marginal zone, red blood cells and macrophagocytes. (2) Visfatinpositive cells were mainly distributed in the red pulp of the spleen, with less in splenic nodules and periarterial lymphatic sheath. In the LPStreated group, the signal intensity and quantity of the visfatin-positive cells were significantly higher in the red pulp and the ellipsoids of the spleen $(\mathrm{P}<0.01)$, whereas lower in the periarterial lymphatic sheath. These results indicate that LPS stimulation induces inflammation, causing the histological changes of the piglet spleen and activating humoral immune response. Moreover, variation of visfatin in the spleen suggests that lymphocytes and macrophages are the potent source of visfatin which participates in the humoral immune response in the inflammation.

KEY WORDS: Visfatin; Spleen; Lipopolysaccharide; Piglets.

\section{INTRODUCTION}

Visfatin, discovered in 2005, is secreted by fat cells and particularly expressed at high levels in visceral fat cells. Visfatin was identified first as a pre-B cell colony-enhancing factor (PBEF) (Samal et al., 1994). PBEF is a pre-B cell growth factor that is mainly expressed in bone marrow, liver, muscle, and active lymphocytes. PBEF can up-regulate the level of interleukins 6 and 8, promote inflammation and participate in immune inflammatory response. It is widely expressed in liver, uterus, and pancreatic cells, bone marrow stromal cells, activated lymphocytes, macrophages, muscle tissues, embryonic cells and visceral adipose tissue (Samal et al.; Ognjanovic et al., 2002; Fukuhara et al., 2005; Tilg \& Moschen, 2008). It has been demonstrated that visfatin can facilitate adipogenesis and accumulation of fat, and exert potent insulin-mimetic effects. In addition, recent findings suggested a link between visfatin, diabetes and obesity and also an association between adipose tissue and inflammation. Hence, the mechanism of action of visfatin has recently attracted widespread attention.

At present, the research on visfatin mainly focuses on acute and chronic inflammatory disorders, obesity and metabolic diseases (Stephens \& Vidal-Puig, 2006; Zhu et al., 2008; Bao et al., 2009; Eker et al., 2010; Huang et al., 2011; Al-Suhaimi \& Shehzad, 2013). In a pilot study, we demonstrated that visfatin was expressed in the immune organs of mice and chickens. At certain levels, visfatin significantly impacts on the structure of immune organs and the level of IFN- in serum (Song et al., 2014). These data indicated that visfatin was involved in immune response. We conducted an experiment using a stress-induced model to study the morphological changes of spleen and the expression level of visfatin in LPS-stimulated piglets. Clarification on the role of visfatin in the immune response may provide a new direction for the treatment of metabolic and autoimmune diseases.

\section{MATERIAL AND METHOD}

Sample collection and processing. Ten healthy large white weaned piglets ( 21 days) were provided by the Mensuration and Research Center of Swine in Huazhong Agricultural

* College of Veterinary Medicine, Huazhong Agricultural University, Wuhan, P.R. China.

** Xinyang College of Agriculture and Forestry, Xinyang, P.R. China. 
University and assigned to two groups $(\mathrm{n}=5)$. All procedures were approved by the Animal Care and Welfare Committee of our University. Each group received an injection intraperitoneally as follows: (1) saline group, piglets received a single-dose of $0.9 \% \mathrm{NaCl}$ solution (CAS: 7647-14-5, Sinopharm, China); (2) LPS group, piglets received a single-dose injection of LPS (O55: B5, sigma) $(100 \mathrm{mg} / \mathrm{kg}$ body weight). All animals were sacrificed at $6 \mathrm{~h}$ under deep anesthesia using pentobarbital $(20 \mathrm{mg} / \mathrm{kg}$ body weight by intravenous injection) after injection. Spleen tissue specimens were quickly removed, fixed with $4 \%$ paraformaldehyde (buffered with $0.1 \mathrm{M}$ phosphate buffer, Sinopharm, China), and subsequently embedded in paraffin. Spleen samples were allocated for histopathological and immunohistochemical investigations. Stained sections were analyzed under a light microscope (BX51; Olympus, Tokyo, Japan) with a digital camera (DP72; Olympus, Tokyo, Japan).

The experiments were conducted according to the rules of the China Management Regulations of Experimental Animals and were licensed by the local authorities. This is in accordance with the International Guiding Principles for Biomedical Research Involving Animals.

Immunohistochemistry procedure and result judgments. The paraffin sections were dewaxed, immersed in $0.01 \mathrm{M}$ PBS (phosphate buffer) buffer for $5 \mathrm{~min}$, then placed in plastic containers containing $0.01 \mathrm{M}$ citrate buffer ( $\mathrm{pH}$ 6.0) to retrieve the antigen for $20 \mathrm{~min}$, followed by cooling to room temperature. The sections were incubated with $0.3 \%$ $\mathrm{H}_{2} \mathrm{O}_{2}$ for 20 min to inactivate endogenous peroxides, washed with PBS 2-3 times for 5 min each time and blocked by 5\% normal goat serum for $20 \mathrm{~min}$ at room temperature. Subsequently, the tissues were incubated with the diluted primary antibody (rabbit anti-visfatin, 1/100, Bioss, China) in a humid chamber at $4^{\circ} \mathrm{C}$ overnight. Meanwhile, negative control was incubated with PBS instead of antibody. After washing 3 times for $5 \mathrm{~min}$ in PBS, the tissues were immerse in a mixture of biotinylated sheep anti-rabbit (Bioss, China) secondary antibodies for $20 \mathrm{~min}$ at 37 . Afterwards, the sections were washed with PBS, incubated with SABC (StreptavidinBiotin Complex) at room temperature for $20 \mathrm{~min}$, and thoroughly washed by PBS 4 times. Finally, visualization was achieved with a DAB kit (Bioss Co., China).

The densities of visfatin-positive cells in various regions of the spleen were estimated. After taking digital photographs under a light microscope with a digital camera, the Integral optical density (IOD) of the visfatin-positive cells in each section and the area of the related regions in each section were measured using an Image Pro Plus analysis system. Ten fields were selected from each section and for determination of expression values of immunopositive cells.
Results are expressed as the Means \pm Standard errors (Means \pm S.E.).

Result judgment standards. The cytoplasm of positive cells stained a brownish yellow. Based on the color of the staining, we divided positive cells into 3 levels referring to the method of Ji et al. (2005): (+++) dark brown, strong positive; $(++)$ medium coloring, brown, positive; and (+) light coloring, light yellow, weakly positive. The staining in control group slices was negative (-), revealing no positive staining within the cells.

Statistical analysis. Statistical analyses were performed using SPSS 17.0 software for Windows. All data were expressed as Mean \pm S.D. values ( $n=5)$. Differences between mean values were compared using the Student's t-test and were considered statistically significant at $\mathrm{P}<0.05$.

\section{RESULTS}

Morphological changes of spleen in LPS-induced piglets. In LPS-treated piglets, the spleen appeared swollen, with increased volume, thickened capsules, blunt edge, cut surface uplifted, and rich blood. Microscopic observation revealed incrassated splenic capsule, thickened trabecular, dissolved and relaxed capsule and trabecular smooth muscle (Fig. 1a, b). White pulp volume was diminished. The majority of the periarterial lymphatic sheathes were increased in area twofold or more. Furthermore, a large number of lymphocytes and reticular cells appear necrotic with nuclear condensation or fragmentation (Fig. 1c). The quantity and volume of spleen nodules was increased, with the obvious germinal center and more lymphocytes (Fig. 1c, d). Red pulp was mainly composed of splenic cords and sinus blood. The splenic cords were filled with much blood, clearly indicating bleeding. Erythrocytosis and lymphocytopenia were evident. The quantity of reticular cells was degenerated and necrotic. Splenic sinus lacuna were increased (Fig. 1e, f), and the number of macrophages was increased. Additionally, the quantity of ellipsoid cells was increased in the LPS group.

Changes in expression of visfatin immunoreactive cells in the spleen of the LPS-treated piglets. The distribution of visfatin-positive cells in the spleen of piglets Visfatinpositive cells were round or oval, ranging in color from yellow to brown, with most positive immunostaining in the cytoplasm. Some nuclei showed a light yellow color, whereas the negative control showed no coloring. Visfatin-positive cells were widely distributed, especially expressed in red pulp as demonstrated by strongly positive immunoreactive products. Visfatin-positive cells were also positively 

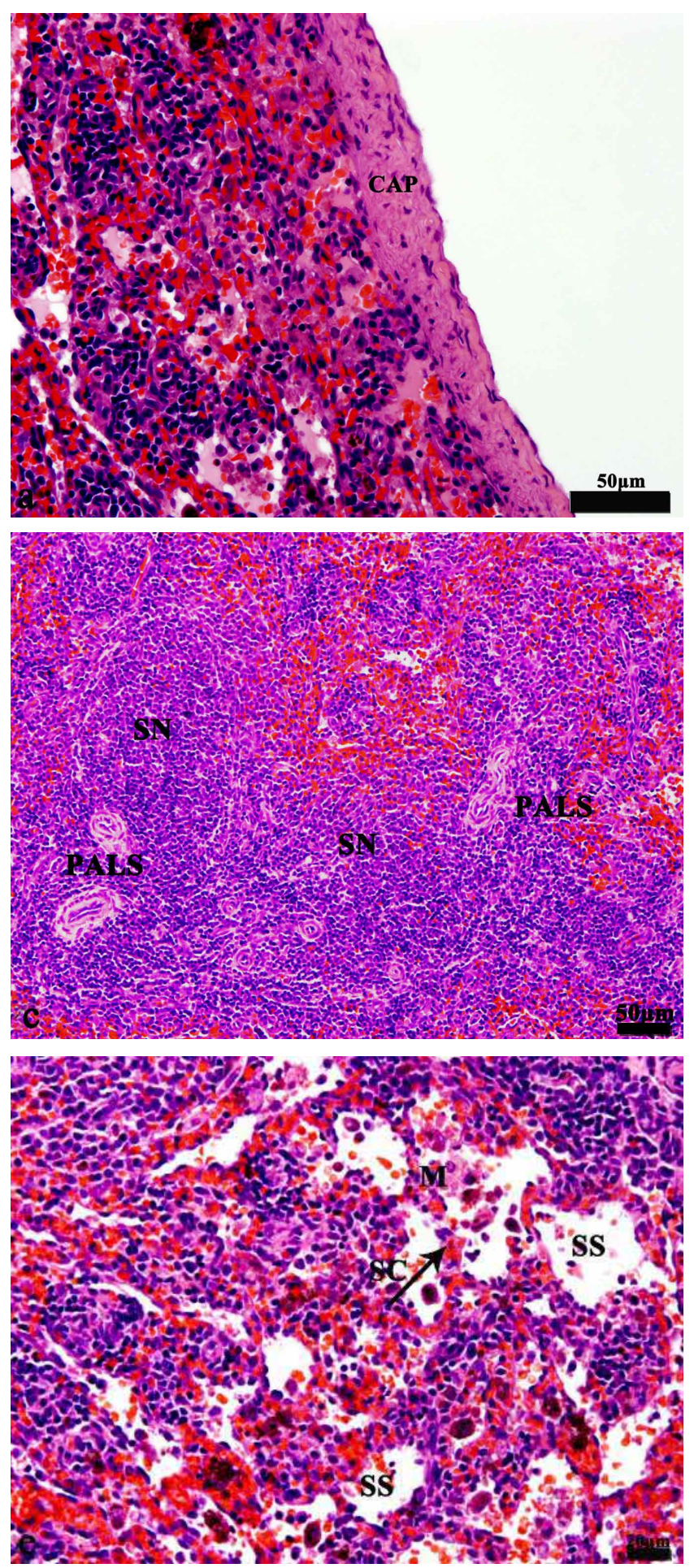

Fig. 1. Histopathological evaluation of spleen tissues. a, c and e: LPS group, with thickened capsule (CAP), strong inflammatory reaction around periarterial lymphatic sheath (PALS), prominent splenic nodules (SN), splenic sinus (SS) and macrophages (M) in red pulp; b, d and f: saline group, with thin capsule (CAP) and weak inflammatory reaction. HE staining. Bars: x200 (a, b, c and d); Bars: x400 (e and f).

expressed in the periarterial lymphocytic sheath and splenic nodules, but the quantity was less. Visfatin was rarely
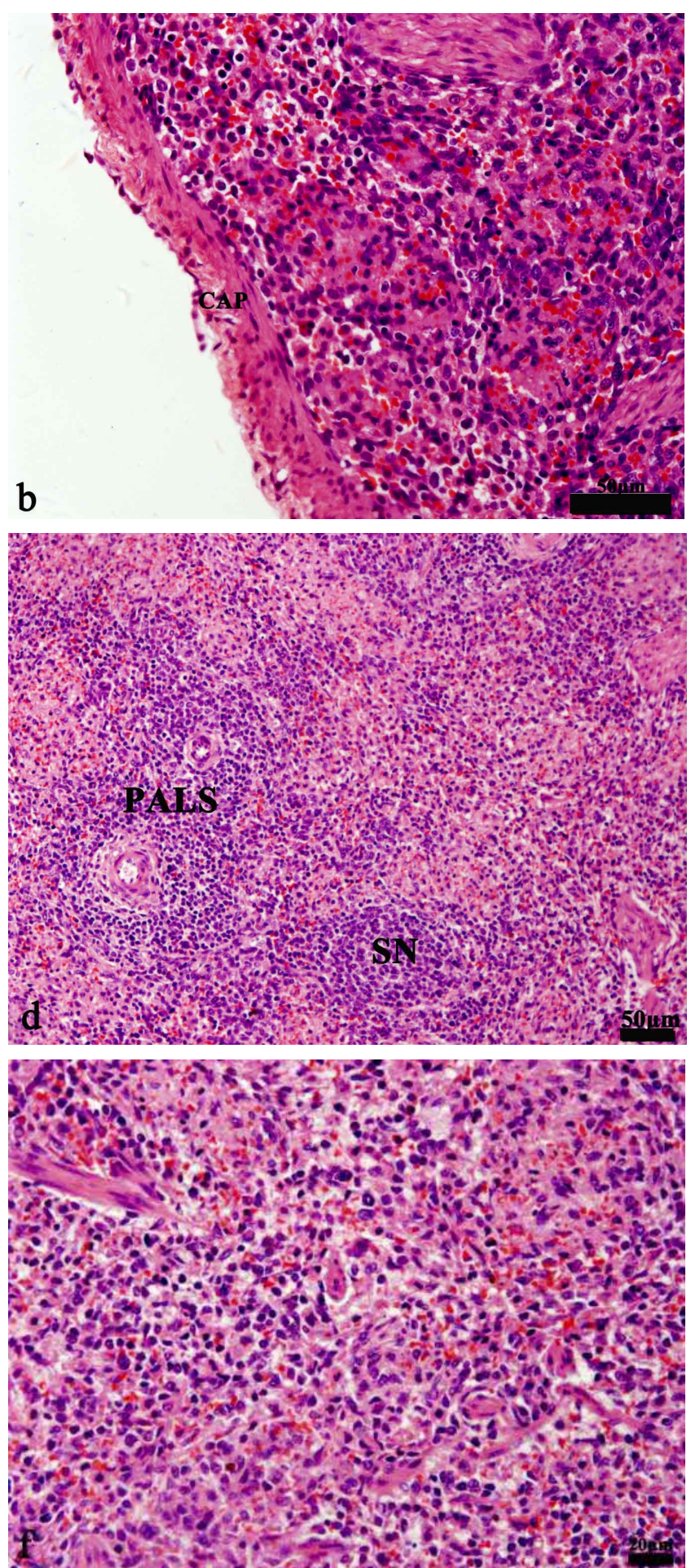

expressed in the ellipsoids, being mainly located in the cytoplasm outside the sheath capillary tube (Fig. 2b, d). 
The expression of visfatin in the spleen of LPS-stimulated piglet. Microscopic observations showed that visfatin immunoreactive cells were present showing diverse morphology such as round, oval, spindle, polymorphic. The quantity of visfatin positive cells in the red pulp was significantly higher than that of the control group. Moreover, the visfatin expression after LPS treatment was extremely statistically significantly higher in the red pulp then that found in saline group $(\mathrm{P}<0.01$; Fig. 2a, b). The quantity and intensity of visfatin-positive cells were both increased in the white pulp $(\mathrm{P}<0.05)$. The distribution of visfatin immunoreactive cells was reduced in the periarterial lymphatic sheath, meanwhile the positive products were weakened $(\mathrm{P}<0.05$; Fig. $2 \mathrm{c}, \mathrm{d})$. The quantity and intensity of visfatin immunoreactive cells in the ellipsoid region of the marginal zone were significantly higher than that of the saline group $(\mathrm{P}<0.01 ;$ Fig. $2 \mathrm{e}, \mathrm{f})$. The specific variation was shown in Table I.
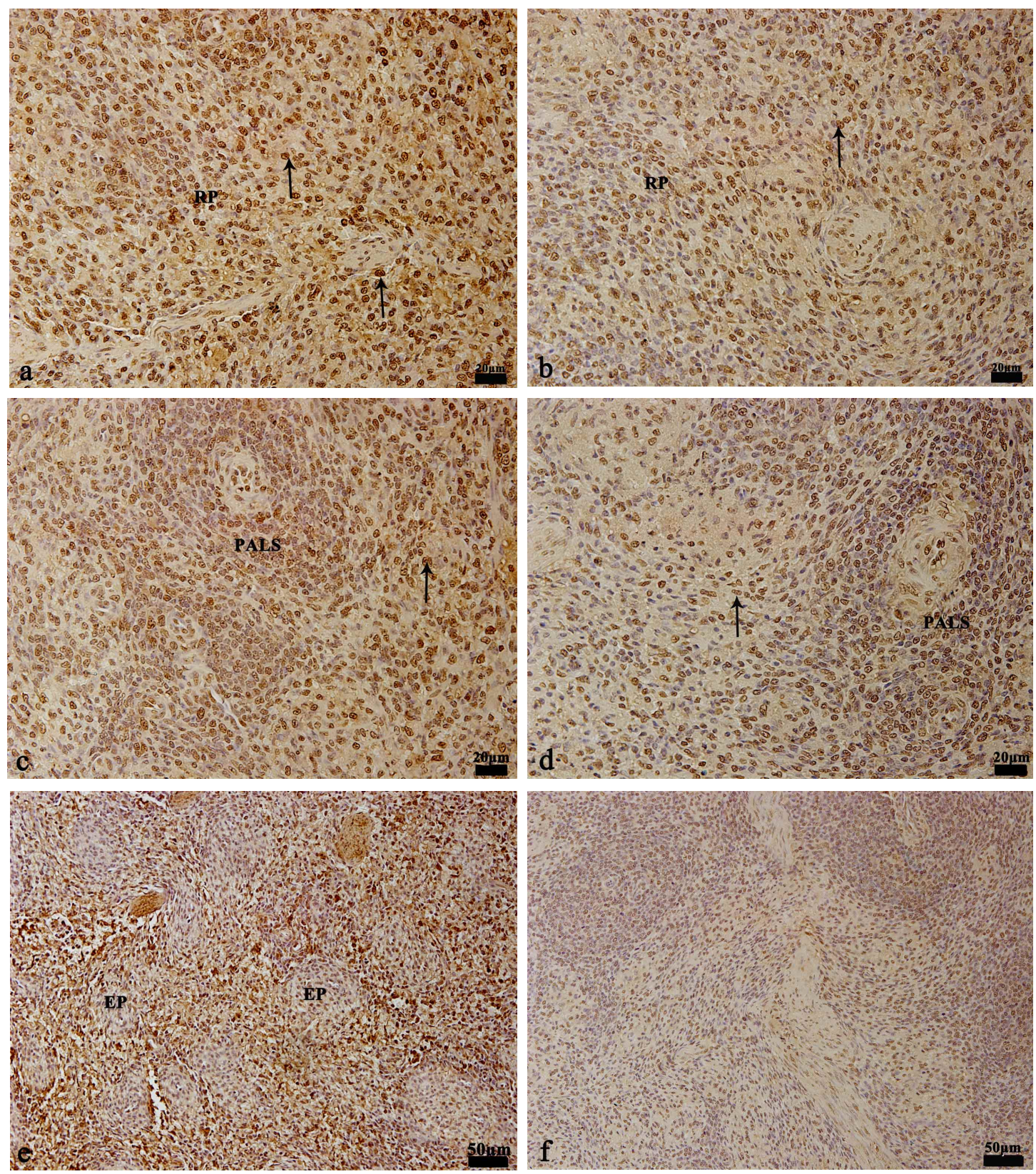

Fig. 2. Immunohistochemical expression of visfatin in LPS group and saline group. a, c and e: LPS group, with strong immunopositive reaction of visfatin. Visfatin-positive cells (arrow) in red pulp (RP), periarterial lymphoid sheath (PALS) and ellipsoid sheath (EP); b, d and f: saline group, with weak immunopositive reaction of visfatin; SABC technique, Harris hematoxyline counter staining, DAB chromogen. Bars: x400 (a, b, c and d); Bars: x200 (e and f). 
Table I. The distribution of visfatin immunoreactive cells in piglet spleen.

\begin{tabular}{lllccc}
\hline \multirow{2}{*}{ Organ } & \multirow{2}{*}{ Location } & \multirow{2}{*}{ Group } & \multicolumn{3}{c}{ Visfatin immunoreactive cells } \\
\cline { 3 - 5 } & & IOD & Density (Mean) & Strong or weak \\
\hline \multirow{2}{*}{ Red pulp } & LPS group & $12583.42 \pm 1296.01^{* *}$ & $2061.66 \pm 767.28$ & +++ \\
& & Saline group & $6874.35 \pm 771.43^{* *}$ & $1261.93 \pm 613.84$ & +++ \\
\multirow{4}{*}{ Spleen } & LPS group & $3469.96 \pm 844.91^{*}$ & $463.04 \pm 160.06$ & ++ \\
& \multirow{2}{*}{ Splenic nodules } & Salinel group & $1411.85 \pm 42.20^{*}$ & $218.94 \pm 11.77$ & + \\
& \multirow{2}{*}{ Periarterial } & LPS group & $1627.38 \pm 271.35$ & $161.10 \pm 49.23^{*}$ & + \\
& lymphatic sheath & Saline group & $1907.64 \pm 800.47$ & $549.70 \pm 202.31^{*}$ & ++ \\
& Ellipsoid & LPS group & $1325.92 \pm 395.84^{* *}$ & $116.30 \pm 26.24$ & + \\
\end{tabular}

Note: $* *=$ indicates significant difference $(\mathrm{P}<0.01) ; *=$ indicates difference $(\mathrm{P}<0.05)$.

\section{DISCUSSION}

Histological comparison of spleen between the LPS group and the saline group. The spleen is the largest peripheral lymphoid organ in the body. Located in the blood circulation pathway, the spleen plays important roles in filtering the blood and inducing immune responses to antigens (Peng, 2009). The spleen is susceptible to irritation and damage from inflammation during the process of combatting, processing and clearing the pathogens in the blood.

The present study found that the spleen treated with LPS was changed in tissue morphology, such as capsule thickening and coarser trabeculae, due to proliferation of connective tissue in the capsule and trabeculae, accompanied by swelling and dissolution of the smooth muscle, collagen fibers, and elastic fibers. Erythrocytes and ellipsoids increased in red pulp, and much blood filled the red pulp, which in turn caused the spleen to swell and the volume to increase.

Splenic nodules are mainly composed of B cells. When stimulated by an antigen, splenic nodules increased and participate in the body ${ }^{-}$s immune response (Peng). In the present study, the number of splenic nodules in the LPS group was increased, and the germinal center became obvious, showing that humoral immune response was enhanced in immune-stressed piglets. After stimulation with an antigen, lymphoid tissue changes due to the emergence and proliferation of pyronine lymphocytes in immune responses (Ward et al., 1959; Thorbecke et al., 1994). Pyronine lymphocytes are lymphocytes or plasma cells stimulated by an antigen. LPS is an activating agent of Tcell independent B-cell mitogens and monocytes/ macrophages, which can cause an acute phase reaction of liver, macrophages and B cells, leading to shock and death (Andersson et al., 1972; Hurley, 1995; Burrell, 1990). It was previously considered that this mechanism did not involve
T-lymphocytes (Hurley). However, Castro and his colleagues have reported that administration of LPS to spleen activated all $\mathrm{B}$ cells and most T cells (CD4 and CD8 T cells), and increased the expression of the activation marker CD69. Massive T cells apoptosis was seen following LPS exposure in the spleen (Castro et al., 1998). In the present study, the periarterial lymphatic sheath of the spleen of the LPS group showed aggregation and thinning in shape, with a decrease in the quantity of lymphocytes. The histological changes of spleen demonstrate that the number of T lymphocytes in the inner periarterial lymphatic sheath decreases markedly after LPS injection, which is consistent with the results of previous studies (Groeneveld et al., 1985; Castro et al.). The reduction of intrasplenic T cells may be due to the increase of apoptosis which was related to LPS-activated B cells. It has been reported that LPS-stimulated splenic B cells have accessory roles in initiating/modulating T-cell immune responses $(\mathrm{Xu}$ et al., 2008). However, the specific mechanisms require further study.

Visfatin-positive cell distribution and changes in piglet spleen. Visfatin is an adipocytokine that is highly expressed in visceral fat. It can promote the synthesis and accumulation of adipose tissue, regulate lipid and glucose metabolism, and participate in immune and inflammatory responses (Fukuhara et al.; Moschen et al., 2007; Tilg \& Moschen). Visfatin corresponds to a protein identified previously as pre-B cell colony-enhancing factor (PBEF) (Samal et al.). $\mathrm{PBEF}$ is mainly distributed in the bone marrow, liver, muscle and activated lymphocytes. PBEF appears to exist more abundantly in the cellular nuclei than in the cytoplasm of non-proliferating cells, but more abundantly in the cytoplasm than in the nuclei of proliferating cells, suggesting that PBEF is a cell cycle-associatedintracellular protein (Kitani et al., 2003). In this study, it was observed that the nucleus of the visfatin immunoreactive cells is round and large, with little 
cytoplasm and small volume. Based on the morphology and the distribution of the visfatin immunoreactive cells in the spleen, we could conclude that visfatin mainly comes from lymphocytes. The positive products were distributed in lymphocyte cytoplasm and nuclei, which indicate that visfatin may be associated with the cell cycle. Visfatinpositive staining was mostly observed in the cytoplasm of lymphocytes, which is common of proliferating cells. The ellipsoid region is located in the marginal zone of the piglet spleen, composed of the sheath capillaries and surrounding macrophages and reticular cells (Peng). Immunohistochemical analysis demonstrated that visfatin immunoreactive products were also distributed in the cytoplasm around the ellipsoid, indicating that in addition to the lymphocytes, macrophages are also one of the sources of visfatin. This finding is consistent with a report that visfatin is mainly released from macrophages of visceral white adipose tissue (Curat et al., 2006). Macrophages are immune cells, a pro-inflammatory cytokine, suggesting that visfatin plays a role in immune and inflammatory response.

Microscopic observation and statistical analysis results showed that after LPS treatment, visfatin immunoreactive cells were mostly expressed in the red pulp where the immunoreactive products were strongly positive $(\mathrm{P}<0.01)$. Additionally, a similar situation occurs in the splenic nodules in the white pulp $(\mathrm{P}<0.05)$. However, visfatin was rarely expressed in the periarterial lymphatic sheath with weak immunoreactivity $(\mathrm{P}<0.05)$. Judging by the variation of the distribution of visfatin immunoreactive cells after LPS treatment, it is speculated that visfatin mainly originates from B lymphocytes since activated B cells can induce the expression of visfatin in an immunestressed state. The variation of the expression and the changes of the positive products shows that visfatin participate in the humoral immune response under inflammatory conditions. In addition, after LPS administration, the increase of the quantity of visfatin positive cells in the ellipsoid region, and the enhancement of product signal further confirmed that macrophages are also an important source of visfatin and that visfatin participates in the body's immune response.

\section{ACKNOWLEDGEMENTS}

We acknowledge grant support from the «Fundamental Research Funds for the Central Universities» $\left(\mathrm{N}^{\circ}\right.$. 2012SC02). The research leading to these results has received funding from the National Natural Science Foundation of China under grant agreement No. 31101776.

XIAO, K.; QIU, C-W.; CHEN, M.; YANG, Z.; WANG, J.; PENG, K-M. \& SONG, H. Distribución y expresión de células visfatin positivas en el bazo de lechones estimulados con lipopolisacáridos. Int. J. Morphol., 32(4):1457-1463, 2014.

RESUMEN: Se presentan los cambios histológicos en el bazo y la expresión inmunohistoquímica de visfatin en lechones estimulados mediante lipopolisacáridos (LPS) con el objetivo de estudiar la relación entre visfatin e inflamación. Los resultados fueron los siguientes: (1) Después del tratamiento por LPS se observaron en el bazo cápsulas más gruesas y trabéculas, una vaina linfática periarterial más delgada, y más sinusoides esplénicos expandible, con un aumento en el número de nódulos esplénicos, linfocitos, elipsoides de la zona marginal, como también un aumento de las células rojas de la sangre y los macrofagocitos. (2) Las células visfatinapositivas se distribuyeron principalmente en la pulpa roja del bazo, con una cantidad menor en los nódulos esplénicos y la vaina linfática periarterial. En el grupo tratado con LPS, la intensidad de la señal y número de células positivas fueron significativamente mayor en la pulpa roja y los elipsoides del bazo $(\mathrm{P}<0,01)$, mientras que estas fueron menores en la vaina linfática periarterial. Estos resultados indican que la estimulación con LPS induce la inflamación provocando cambios histológicos del bazo de los lechones y la activación de la respuesta inmune humoral. Por otra parte, la variación de visfatin en el bazo sugiere que los linfocitos y los macrófagos son una fuente potente de visfatin en la respuesta inmune humoral de la inflamación.

PALABRAS CLAVE: Visfatin; Bazo; Lipopolisacárido; Lechones.

\section{REFERENCES}

Al-Suhaimi, E. A. \& Shehzad, A. Leptin, resistin and visfatin: the missing link between endocrine metabolic disorders and immunity. Eur. J. Med. Res., 18:12, 2013.

Andersson, J.; Sjöberg, O. \& Möller, G. Mitogens as probes for immunocyte activation and cellular cooperation. Transplant. Rev., 11:131-77, 1972.
Bao, J. P.; Chen, W. P. \& Wu, L. D. Visfatin: a potential therapeutic target for rheumatoid arthritis. J. Int. Med. Res., 37(6):165561, 2009.

Burrell, R. Immunomodulation by bacterial endotoxin. Crit. Rev. Microbiol., 17(3):189-208, 1990. 
Castro, A.; Bemer, V.; Nóbrega, A.; Coutinho, A. \& Truffa-Bachi, P. Administration to mouse of endotoxin from gram-negative bacteria leads to activation and apoptosis of T lymphocytes. Eur. J. Immunol., 28(2):488-95, 1998.

Curat, C. A.; Wegner, V.; Sengenès, C.; Miranville, A.; Tonus, C.; Busse, R. \& Bouloumié, A. Macrophages in human visceral adipose tissue: increased accumulation in obesity and a source of resistin and visfatin. Diabetologia, 49(4):744-7, 2006

Eker, S.; Ayaz, L.; Tamer, L. \& Ulubas, B. Leptin, visfatin, insulin resistance, and body composition change in chronic obstructive pulmonary disease. Scand. J. Clin. Lab. Invest., 70(1):40-4, 2010.

Fukuhara, A.; Matsuda, M.; Nishizawa, M.; Segawa, K.; Tanaka, M.; Kishimoto, K.; Matsuki, Y.; Murakami, M.; Ichisaka, T.; Murakami, H.; Watanabe, E.; Takagi, T.; Akiyoshi, M.; Ohtsubo, T.; Kihara, S.; Yamashita, S.; Makishima, M.; Funahashi, T.; Yamanaka, S.; Hiramatsu, R.; Matsuzawa, Y. \& Shimomura, I. Visfatin: a protein secreted by visceral fat that mimics the effects of insulin. Science, 307(5708):42630,2005

Groeneveld, P. H.; Koopman, G. \& van Rooijen, N. The effects of LPS on the cellular composition of the splenic white pulp in responder $\mathrm{C} 3 \mathrm{H} / \mathrm{He}$ and non-responder $\mathrm{C} 3 \mathrm{H} / \mathrm{HeJ}$ mice. Virchows Arch. B Cell Pathol. Incl. Mol. Pathol., 49(2):18393, 1985.

Huang, J. F.; Huang, C. F.; Yu, M. L.; Dai, C. Y.; Huang, C. I.; Yeh, M. L.; Hsieh, M. H.; Yang, J. F.; Hsieh, M. Y.; Lin, Z. Y.; Chen, S. C. \& Chuang, W. L. Serum visfatin is correlated with disease severity and metabolic syndrome in chronic hepatitis C infection. J. Gastroenterol. Hepatol., 26(3):530-5, 2011.

Hurley, J. C. Endotoxemia: methods of detection and clinical correlates. Clin. Microbiol. Rev., 8(2):268-92, 1995.

Ji, X. L.; Shi, Z. L. \& Shen, M. S. Immunohistochemistry new. Beijing, People’s Military Medical Press, 2005.

Kitani, T.; Okuno, S. \& Fujisawa, H. Growth phase-dependent changes in the subcellular localization of pre-B-cell colonyenhancing factor. F. E. B. S. Lett., 544(1-3):74-8, 2003.

Moschen, A. R.; Kaser, A.; Enrich, B.; Mosheimer, B.; Theurl, M.; Niederegger, H. \& Tilg, H. Visfatin, an adipocytokine with proinflammatory and immunomodulating properties. $J$. Immunol., 178(3):1748-58, 2007.

Ognjanovic, S. \& Bryant-Greenwood, G. D. Pre-B-cell colonyenhancing factor, a novel cytokine of human fetal membranes. Am. J. Obstet. Gynecol., 187(4):1051-8, 2002.

Peng, K. M. Animal Histology and Embryology. Beijing, Higher Education Press, 2009. pp.115-7.
Samal, B.; Sun, Y.; Stearns, G.; Xie, C.; Suggs, S. \& McNiece, I. Cloning and characterization of the cDNA encoding a novel human pre-B-cell colony-enhancing factor. Mol. Cell. Biol., 14(2):1431-7,1994.

Song, H.; Lin Q. X.; Li, R. A.; Xiao, K. \& Peng, K. M. The Expression of Visfatin in Mouse Ovary and its Regulatory on IFN-. Pak. Vet. J., 34(2):180-4, 2014.

Stephens, J. M. \& Vidal-Puig, A. J. An update on visfatin/pre-B cell colony-enhancing factor, an ubiquitously expressed, illusive cytokine that is regulated in obesity. Curr. Opin. Lipidol., 17(2):128-31, 2006.

Thorbecke, G. J.; Amin, A. R. \& Tsiagbe, V. K. Biology of germinal centers in lymphoid tissue. FASEB J., 8(11):832-40, 1994.

Tilg, H. \& Moschen, A. R. Role of adiponectin and PBEF/visfatin as regulators of inflammation: involvement in obesityassociated diseases. Clin. Sci. (Lond.), 114(4):275-88, 2008.

Ward, P. A., Johnson, A. G. \& Abell, M. R. Studies on the adjuvant action of bacterial endotoxins on antibody formation. III. Histologic response of the rabbit spleen to a single injection of a purified protein antigen. J. Exp. Med., 109(5):463-74, 1959.

Xu, H.; Liew, L. N.; Kuo, I. C.; Huang, C. H.; Goh, D. L.; \& Chua, K. Y. The modulatory effects of lipopolysaccharide-stimulated $\mathrm{B}$ cells on differential T-cell polarization. Immunology, 125(2):218-28, 2008.

Zhu, J.; Schott, M.; Liu, R.; Liu, C.; Shen, B.; Wang, Q.; Mao, X.; Xu, K.; Wu, X.; Schinner, S.; Papewalis, C.; Scherbaum, W. A. \& Liu, C. Intensive glycemic control lowers plasma visfatin levels in patients with type 2 diabetes. Horm. Metab. Res., 40(11):801-5, 2008.

\section{Correspondence to: \\ Hui Song \\ College of Veterinary Medicine \\ Huazhong Agricultural University \\ Lion Street 1 \\ Hongshan District \\ Wuhan 430070 \\ CHINA}

Tel: 86-27-8728 6970

Fax: 86-27-8728 0408

Email: songh2007@mail.hzau.edu.cn

Received: 08-07-2014

Accepted: 28-08-2014 